Original Research

\title{
UJI AKTIVITAS ANTIBAKTERI FRAKSI BUTANOL, ETIL ASETAT DAN N-HEKSAN DARI DAUN PEPAYA (Carica Papaya L.) TERHADAP BAKTERI PENYEBAB JERAWAT SECARA IN-VITRO
}

\section{ANTIBACTERIAL ACTIVITY TEST FRACTION N-HEXANE, ETHYL ACETATE AND BUTANOL LEAF PAPAYA (Carica papaya L.) ON THE CAUSES OF ACNE BY BACTERIA IN VITRO}

\author{
Oktafian Nuril Wijaya ${ }^{1}$ *,_Ghalib Syukrillah Syahputra ${ }^{2}$ \\ ${ }^{1,2}$ Fakultas Farmasi, Universitas 17 Agustus 1945, Jakarta, Indonesia, 14356 \\ *E-mail: fianpakhoy@gmail.com
}

Diterima: 20/10/2019

Direvisi: 13/11/2019

Disetujui: 02/12/2019

\begin{abstract}
Abstrak
Penggunaan bahan alam sebagai obat tradisional telah lama dilakukan, Salah satu bahan yang berpotensi adalah daun pepaya. Tujuan pengujian ini untuk mengevaluasi aktivitas antbakteri fraksi N-heksan, Etil asetat, dan Butanol dari daun pepaya (Carica papaya L.) terhadap bakteri Propionibacterium acnes, Staphylococcus epidermidis dan Staphylococcus aureus. Penelitian ini merupakan penelitian eksperimental dengan rancangan post test only control group design. Uji aktivitas anti bakteri dilakukan dengan difusi cakram (Kirby-bauer), kontrol positif menggunakan klindamisin, kontrol negatif menggunakan dmso, serta sampel uji yakni fraksi Butanol, Etil asetat dan N-Heksana. Data yang diperoleh dianalisis menggunakan uji Two way annova. Hasil penelitian menunjukan fraksi N-heksan daun pepaya memiliki aktivitas dalam menghambat pertumbuhan bakteri masiing-masing Staphylococcus epidermidis, Staphylococus aureus dan Propionibacterium acnes paling besar pada konsentrasi konsentraasi 200 $\mu \mathrm{g} /$ disc rerata zona hambat $20,03 \pm 0,45 \mathrm{~mm}, 20,65 \pm 0,21 \mathrm{~mm}$, dan 20,74 $\pm 0,11 \mathrm{~mm}$.
\end{abstract}

Kata kunci : Fraksi; Daun Pepaya; Carica papaya Linn f.; Staphylococcus aureus; Staphylococcus epidermidis; Propionibacterium acnes. 


\begin{abstract}
The use of natural ingredients in traditional medicine has been carried out, one potential material is papaya. The purpose of this test to evaluate the activity antbakteri fraction of $\mathrm{N}$-hexane, ethyl acetate and butanol from the leaves of papaya (Carica papaya L.) against Propionibacterium acnes, Staphylococcus epidermidis and Staphylococcus aureus. This study was an experimental study with post test only control group design. Anti-bacterial activity test performed by disc diffusion (Kirby-bauer), a positive control using clindamycin, using a negative control DMSO, and the test sample that is the fraction of butanol, ethyl acetate and n-hexane. Data were analyzed using Two way Annova test. The results showed N-hexane fraction papaya leaves has an activity in inhibiting the growth of bacteria Staphylococcus epidermidis masiing individual, Staphylococus aureus and Propionibacterium acnes is greatest in concentrationkonsentraasi $200 \mathrm{ug} /$ disc mean inhibitory zone $20.03 \mathrm{~mm} \pm 0.45,20.65 \pm 0.21 \mathrm{~mm}$ and $20.74 \pm 0.11$ $\mathrm{mm}$.
\end{abstract}

Keywords : Faction, Leaf Papaya, Carica papaya Linn. f., Staphylococcus aureus, Staphylococcus epidermidis, Propionibacterium acnes.

\title{
PENDAHULUAN
}

Jerawat merupakan penyakit kulit yang dikenal dengan Acne vulgaris, hampir semua orang pernah mengalaminya. Jerawat sering dianggap sebagai kelainan kulit yang timbul secara fisiologis. Hal ini umumnya terjadi pada umur sekitar 14-17 tahun pada wanita, 16-19 tahun pada pria dan akan menghilang dengan sendirinya pada usia sekitar 20-30 tahun. Namun kadangkadang terutama pada wanita, jerawat menetap sampai dekade umur 30 tahun lebih[1].

Jerawat dapat disebabkan oleh bakteri Propionibacterium acnes, Staphylococcus epidermedis, dan Staphylococcus aureus. Bakteri ini tidak patogen pada kondisi normal, tetapi bila terjadi perubahan kondisi kulit, maka bekteri tersebut berubah menjadi invasif. Sekresi kelenjar keringat dan kelenjar sebasea yang menghasilkan air, asam amino, urea, garam dan asam lemak merupakan sumber nutrisi bagi bakteri. Bakteri ini berperan pada proses kemotaktik inflamasi serta pembentukan enzime lipolitik pengubah fraksi sebum menjadi massa padat, yang menyebabkan terjadinya penyumbatan pada saluran kelenjar sebasea[2]. Indonesia adalah suatu negara kepulauan yang memiliki hutan tropis terbesar kedua di dunia, kaya dengan keanekaragaman hayati. Distribusi tumbuhan tingkat tinggi yang terdapat di hutan tropika Indonesia lebih dari $12 \%$ (30.000) dari yang terdapat di muka bumi (250.000)[3]. Penggunaan tumbuhan sebagai bahan pengobatan merupakan salah satu alternatif untuk menemukan nilai manfaat dari hutan yang ada di Indonesia. Disamping itu, yang tidak kalah menariknya adalah hutan hujan tropis Indonesia memiliki keanekaragaman hayati dapat dipandang sebagai pabrik atau industry bahan-bahan kimia hayati berproduksi sepanjang tahun. Keanekaragaman hayati Indonesia adalah salah satu aset nasional dengan nilai ekonomis yang tinggi, yang merupakan ecological specific dengan comparative advantage[3]. Oleh karena itu, dibutuhkan penelitian lebih lanjut mengenai tanaman-tanaman yang berpotensi mempunyai aktivitas sebagai obat, salah satu tanaman yang berpotensi sebagai antimikroba adalah papaya (Carica papaya $L$.)

Berdasarkan latar belakang tersebut, peneliti tertarik untuk melakukan pengujian lebih lanjut untuk meneliti pada fraksi mana daun papaya memiliki aktivitas antibakteri paling baik, dalam hal ini bakteri uji yang akan digunakan adalah Staphylococcus aureus, Staphylococcus epidermidis, dan Propionibaterium acnes. 


\section{METODE}

\section{Sampel (Bahan) Penelitian}

Daun Pepaya, etanol 70\%, etil asetatat, n-heksan, aquadest, Dmso Pereaksi Karl Fischer, besi (III) klorida, asam klorida, ammonium hidroksida, kloroform, asam asetat anhidrat, asam sulfat pekat, asam klorida pekat, Butanol, logam magnesium, amil alkohol, ammonia, reagen Fehling A, Fehling B, Mayer, Dragendorff, Bouchardat, bakteri Propionibacterium acnes ATCC 37533, Staphylococcus epidermedis Bionumber 01000076620251, Stapylococcus aureus (ATCC 25823), media Brucella Agar, Mueller Hinton Agar (MHA), Brain heart infusion (BHI), Nutrient broth (NB), reagen gram stain, sol. lugol, etanol 96\%, karbol fuchsin, oil immersion, natrium klorida, ferri klorida, McFarland 0,5, lysol, kertas saring Whatman, cotton bud, kapas, kertas cakram kosong, antibiotik Klindamisin.

\section{Prosedurkerja}

\section{Ekstraksi sampel Daun Pepaya}

Serbuk daun pepaya (C.papaya) 500 gram dimaserasi dalam etanol 70\%hingga simplisia terendam dalam pelarut selama 24 jam. Maserasi dilakukanselama 3 hari dengan penggantian pelarut setiap 24 jam selama $2 \mathrm{x}$ pengulangan.Hasil maserasi tersebut tersebut digabungkan kemudian diuapkan menggunakanrotary vacuum evaporator pada suhu 50oC[4].

\section{Identifikasi Kandungan Kimia Ekstrak \\ Identifikasi Alkaloid}

Sebanyak $3 \mathrm{~mL}$ larutan ekstrak ditambahkan dengan $1 \mathrm{~mL} \mathrm{HCl} 2 \mathrm{~N}$ dan $6 \mathrm{~mL}$ aquadest, kemudian dipanaskan selama 2 menit, didinginkan dan disaring. Filtrat diperiksa dengan pereaksi Mayer terbentuk endapan putih, dengan pereaksi dragendorf terbentuk endapan coklat atau jingga, dan dengan pereaksi bouchardad terbentuk endapan coklat[5].

Identifikasi Flavonoid

Sebanyak $2 \mathrm{~mL}$ larutan ekstrak ditambahkan serbuk Mg dan $2 \mathrm{~mL} \mathrm{HCl} \mathrm{2N}$. Senyawa flavonoid akan menunjukkan warna jingga sampai merah[5].

Identifikasi Saponin

Sampel ditambahkan aquades, kemudian dikocok vertikal selama 10 detik. Hasil uji positif jika timbul busa stabil selama 10 menit[5].

Identifikasi Tannin

Sebanyak $1 \mathrm{~mL}$ larutan ekstrak uji direaksikan dengan $\mathrm{FeCl}_{3} \quad 10 \%$ adanya tanin ditunjukkan dengan terbentuknya warna biru tua atau hitam kehijauan[5].

\section{Uji Aktivitas Antiakteri}

Pengujian aktivitas antibakteri dari masing - masing fraksi daun papaya terhadap P.acnes, S.aureus dan S.epidermidis dilakukandengan metode difusi menggunakan kertas cakram.

Medium Drucella Agar untuk bakteri P.acnes dan medium MHA untuk S.aureus dan S.epidermidis yang masih berbentuk cairan dituang ke dalam cawan petri steril $\pm 20 \mathrm{ml}$ dan dibiarkan memadat. Setelah agar memadat, suspensi bakteri sebanyak $100 \mu$ disebar ke permukaan agar secara merata dengan menggunakan lidi kapas steril. 
Kertas cakram steril kemudian ditetesi dengan larutan uji sebanyak $10 \mu \mathrm{l}$ kemudian didiamkan beberapa saat agar pelarutnya menguap kemudian diletakkan di atas permukaan agar. Untuk control negatif digunakan Klindamisin pada setiap bakteri uji. Masing-masing cawan petri kemudian diinkubasi dalam keadaan posisi terbalik pada suhu $37{ }^{\circ} \mathrm{C}$ selama 48 jam dalam kondisi anaerob untuk P.acnes sedangkan untuk S.aureus dan S.epidermidis pada suhu $37{ }^{\circ} \mathrm{C}$ selama 24 jam dalam kondisi aerob. Aktivitas antibakteri diamati berdasarkan pengukuran diameter daerah hambat atau daerah bening yang terbentuk di sekeliling kertas cakram dikurangi dengan diameter cakram, pengujian dilakukan sebanyak 3 kali pengulangan.

\section{HASIL DAN PEMBAHASAN}

\section{Hasil Ekstraksi Daun Pepaya}

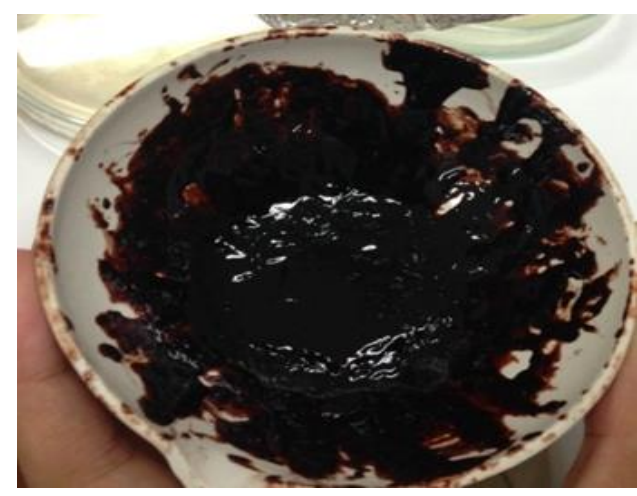

Gambar 1. Ekstrak daun pepaya

Tabel 1 Karakteristik ekstrak etanol daun pepaya

\begin{tabular}{|c|c|}
\hline Karakteristik ekstrak & Hasil \\
\hline Bentuk & Ekstrak Kental \\
Warna & Hijau pekat \\
Bau & Khas \\
Rasa & Pahit \\
\hline
\end{tabular}


Setelah perendaman, larutan yang didapat disaring menggunakan kertas saring dan diperoleh filtrat berwarna merah kecoklatan. Kemudian filtrat dipekatkan menggunakan rotary evaporator pada suhu $50^{\circ} \mathrm{C}$ dengan tekanan $120 \mathrm{rpm}$ sehingga didapatkan ekstrak kental dengan nilai rendemen sebesar $12,69 \%$.

\section{Hasil Skrinng Fitokimia Daun Pepaya}

Tabel 2. Hasil Uji Fitokimia Ekstrak Etanol Daun Pepaya

\begin{tabular}{|c|l|c|}
\hline No & Senyawa & Hasil \\
\hline 1 & Alkaloid & + \\
\hline 2 & Saponin & + \\
\hline 3 & Tanin & + \\
\hline 4 & Fenolik & + \\
\hline 5 & Flavonoid & + \\
\hline 6 & Triterpenoid & + \\
\hline 7 & Steroid & + \\
\hline 8 & Gliikosida & + \\
\hline
\end{tabular}

\section{Hasil Fraksinasi Daun Pepaya menjadi Fraksi Etil Asetat, Fraksi N-Heksana, dan Fraksi Butanol}

Fraksinasi dilakukan secara bertahap yang bertujuan agar hasil yang didapat lebih maksimal, fraksinasi adalah proses pemisahan pelarut dengan kepolaran yang berbeda tujuannya untuk mengambil senyawa aktif sesuai dengan sifat kepolaranya[6]. Fraksinasi dimulai dengan menimbang ekstrak sebanyak $30 \mathrm{~g}$ lalu dilarutkan dengan butanol sebanyak $70 \mathrm{ml}$ dan air $30 \mathrm{ml}$. Fraksinasi pertama dengan pelarut n-heksana $100 \mathrm{ml}$ sebanyak 3 kali dengan maksud agar diperoleh pemisahan yang maksimal. Berdasarkan hasil fraksinasi dapat diperhatikan ada dua lapisan, lapisan atas berwarna kuning sebanyak dan lapisan bawah merupakan lapisan air dan butanol hal ini terjadi karena sesuai dengan sifat massa jenis dimana larutan yang memiliki massa paling besar akan berada di bagian bawah.Massa jenis $\mathrm{n}$-heksana $0,4 \mathrm{~g} / \mathrm{ml}$ lebih kecil dari pada massa jenis air $1,026 \mathrm{~g} / \mathrm{ml}$. Setelah itu lapisan dipisahkan dan diuapkan di atas penangas air. Diperoleh sebanyak 1,37 g fraksi n-Heksan dengan nilai rendemen 4,5\%

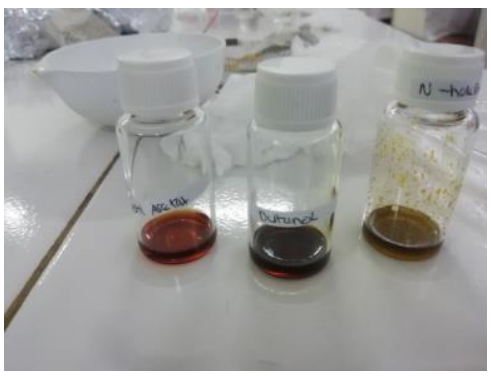

Gambar 2. Fraksi 


\section{Hasil Uji Aktivitas antibakteri}

Pengujian pertama yang dilakukan adalah uji pendahuluan untuk menentukan fraksi mana yang mempunyai aktivitas zona hambat yang paling tinggi.

Tabel 3. Zona Hambat Terhadap Bakteri Propionibacteriuma acnes pada konsentrasi $50 \mu \mathrm{g} / \mathrm{disc}$

\begin{tabular}{|c|c|c|c|c|}
\hline & \multicolumn{3}{|c|}{ Diameter zona hambat } & \multirow{2}{*}{$\begin{array}{c}\text { Rata-rata Diameter Zona } \\
\text { Hambat }(\mathrm{mm}) \pm \mathrm{SD}\end{array}$} \\
\cline { 2 - 4 } $50 \mathrm{\mu g} /$ disc & $\begin{array}{c}\text { perlakuan } \\
1\end{array}$ & $\begin{array}{c}\text { perlakuan } \\
2\end{array}$ & $\begin{array}{c}\text { pelakuan } \\
3\end{array}$ & $19.61 \pm 0.14$ \\
\hline kontrol + & 19.54 & 19.78 & 19.52 & $6.55 \pm 0.11$ \\
\hline $\begin{array}{c}\text { fraksi } \mathrm{n}- \\
\text { heksan }\end{array}$ & 6.45 & 6.53 & 6.68 & $4.9 \pm 0.19$ \\
\hline $\begin{array}{c}\text { fraksi etil } \\
\text { asetat }\end{array}$ & 5.12 & 4.77 & 4.81 & $5.39 \pm 0.33$ \\
\hline $\begin{array}{c}\text { fraksi } \\
\text { butanol }\end{array}$ & 5.12 & 5.77 & 5.3 & \\
\hline
\end{tabular}

Tabel 4. Zona Hambat Terhadap Bakteri Propionibacteriuma acnes pada Konsentrasi 100 $\mu \mathrm{g} /$ disc.

\begin{tabular}{|c|c|c|c|c|}
\hline & \multicolumn{3}{|c|}{ Diameter Zona Hambat } & \multirow{2}{*}{$\begin{array}{c}\text { Rata-rata Diameter Zona } \\
\text { Hambat }(\mathrm{mm}) \pm \text { SD }\end{array}$} \\
\cline { 1 - 3 } $100 \mu \mathrm{g}$ & $\begin{array}{c}\text { perlakuan } \\
1\end{array}$ & $\begin{array}{c}\text { perlakuan } \\
2\end{array}$ & $\begin{array}{c}\text { pelakuan } \\
3\end{array}$ & $20.74 \pm 0.11$ \\
\hline kontrol + & 20.72 & 20.82 & 20.67 & $18.75 \pm 0.11$ \\
\hline $\begin{array}{c}\text { fraksi } \mathrm{n}- \\
\text { heksan }\end{array}$ & 18.79 & 18.70 & 18.34 & $17.41 \pm 0.50$ \\
\hline $\begin{array}{c}\text { fraksi etil } \\
\text { asetat }\end{array}$ & 16.53 & 17.27 & 17.77 & $14.75 \pm 0.97$ \\
\hline $\begin{array}{c}\text { fraksi } \\
\text { butanol }\end{array}$ & 13.23 & 15.46 & 14.54 & \\
\hline
\end{tabular}

Tabel 5. Zona Hambat Terhadap Bakteri Propionibacteriuma acnes pada Konsentrasi 200 $\mu \mathrm{g} / \mathrm{disc}$

\begin{tabular}{|c|c|c|c|c|}
\hline & \multicolumn{3}{|c|}{ Diameter zona hambat } & \multirow{2}{*}{$\begin{array}{c}\text { Rata-rata Diameter Zona } \\
\text { Hambat }(\mathrm{mm}) \pm \text { SD }\end{array}$} \\
\cline { 1 - 4 } $200 \mu \mathrm{g}$ & $\begin{array}{c}\text { perlakuan } \\
1\end{array}$ & $\begin{array}{c}\text { perlakuan } \\
2\end{array}$ & $\begin{array}{c}\text { pelakuan } \\
3\end{array}$ & $22.41 \pm 0.50$ \\
\hline $\begin{array}{c}\text { kontrol }+ \\
\text { fraksi n- } \\
\text { heksan }\end{array}$ & 21.97 & 22.59 & 22.78 & $20.74 \pm 0.11$ \\
\hline $\begin{array}{c}\text { fraksi etil } \\
\text { asetat }\end{array}$ & 19.34 & 19.58 & 19.05 & $19.74 \pm 0.11$ \\
\hline $\begin{array}{c}\text { fraksi } \\
\text { butanol }\end{array}$ & 18.66 & 17.76 & 18.55 & $18.41 \pm 0.55$ \\
\hline
\end{tabular}




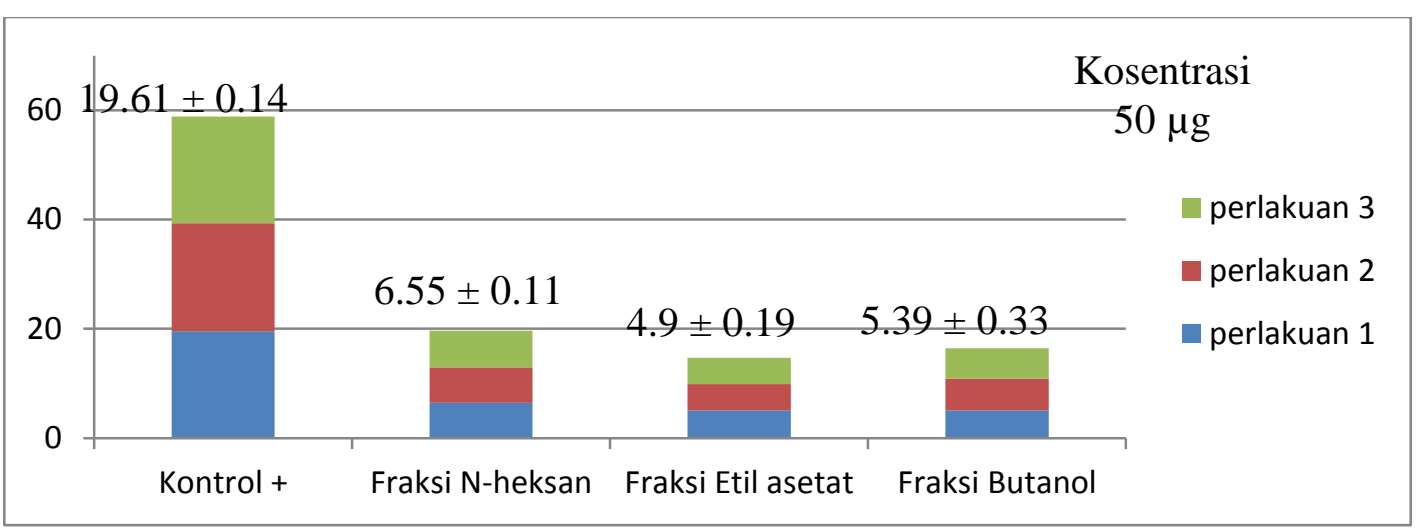

Gambar 3. Grafik Rata-Rata Diameter Zona Hambat Fraksi N-heksan, Etil Asetat, dan Butanol pada bakteri Proponibacterium acnes dengan konsentrasi $50 \mu \mathrm{g} / \mathrm{disc}$,

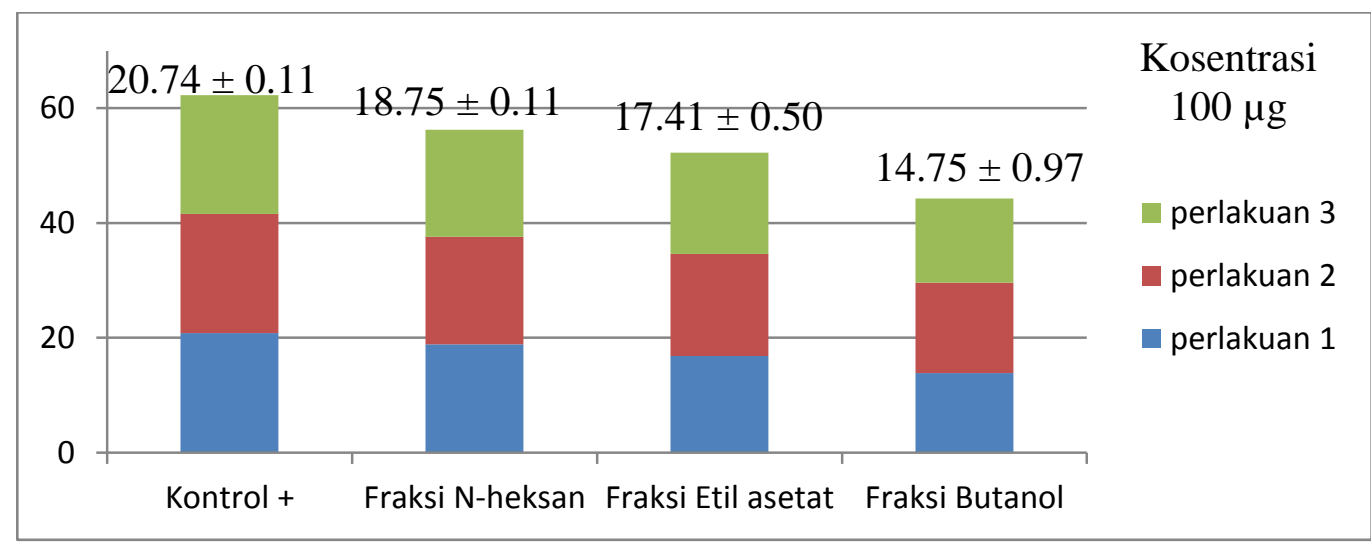

Gambar 4. Grafik Rata-Rata Diameter Zona Hambat Fraksi N-heksan, Etil Asetat, dan Butanol pada bakteri Proponibacterium acnes dengan konsentrasi $100 \mu \mathrm{g} / \mathrm{disc}$.

Tabel 6. Zona Hambat Terhadap Bakteri Staphylococcus aureus pada Konsentrasi $50 \mu \mathrm{g} / \mathrm{disc}$.

\begin{tabular}{|c|c|c|c|c|}
\hline & \multicolumn{3}{|c|}{ Diameter zona hambat } & \multirow{2}{*}{$\begin{array}{l}\text { Rata-rata Diameter Zona } \\
\text { Hambat }(\mathrm{mm}) \pm \mathrm{SD}\end{array}$} \\
\hline $50 \mu \mathrm{g}$ & $\begin{array}{c}\text { perlakuan } \\
1\end{array}$ & $\begin{array}{c}\text { perlakuan } \\
2\end{array}$ & $\begin{array}{c}\text { pelakuan } \\
3\end{array}$ & \\
\hline kontrol + & 19.8 & 19.75 & 19.41 & $19.65 \pm 0.21$ \\
\hline $\begin{array}{l}\text { fraksi n- } \\
\text { heksan }\end{array}$ & 6.5 & 6.1 & 6.31 & $6.30 \pm 0.20$ \\
\hline $\begin{array}{l}\text { fraksi } \\
\text { etil } \\
\text { asetat }\end{array}$ & 4.6 & 4.51 & 4.78 & $4.63 \pm 0.13$ \\
\hline $\begin{array}{c}\text { fraksi } \\
\text { butanol }\end{array}$ & 5.15 & 4.41 & 5.6 & $5.05 \pm 0.60$ \\
\hline
\end{tabular}


Tabel 7. Zona Hambat Terhadap Bakteri Staphylococcus aureus pada Konsentrasi 100 Mg/disc.

\begin{tabular}{|c|c|c|c|c|}
\hline & \multicolumn{3}{|c|}{ Diameter zona hambat } & \multirow{2}{*}{$\begin{array}{c}\text { Rata-rata Diameter Zona } \\
\text { Hambat }(\mathrm{mm}) \pm \text { SD }\end{array}$} \\
\cline { 1 - 4 } $100 \mu \mathrm{g}$ & $\begin{array}{c}\text { perlakuan } \\
1\end{array}$ & $\begin{array}{c}\text { perlakuan } \\
2\end{array}$ & $\begin{array}{c}\text { pelakuan } \\
3\end{array}$ & $20.65 \pm 0.08$ \\
\hline $\begin{array}{c}\text { kontrol }+ \\
\text { fraksi } \mathrm{n}- \\
\text { heksan }\end{array}$ & 20.6 & 20.75 & 20.71 & $19.32 \pm 0.40$ \\
\hline $\begin{array}{c}\text { fraksi } \\
\text { etil } \\
\text { asetat }\end{array}$ & 16.8 & 19.65 & 19.37 & $17.32 \pm 0.48$ \\
\hline $\begin{array}{c}\text { fraksi } \\
\text { butanol }\end{array}$ & 16.42 & 14.64 & 15.56 & $15.70 \pm 0.184$ \\
\hline
\end{tabular}

Tabel 8. Zona Hambat Terhadap Bakteri Staphylococcus aureus pada Konsentrasi 200 g/disc

\begin{tabular}{|c|c|c|c|c|}
\hline & \multicolumn{3}{|c|}{ diameter zona hambat } & \multirow{2}{*}{$\begin{array}{l}\text { rata-rata diameter zona } \\
\text { hambat }(\mathrm{mm}) \pm \mathrm{SD}\end{array}$} \\
\hline $200 \mu \mathrm{g}$ & $\begin{array}{c}\text { perlakuan } \\
1\end{array}$ & $\begin{array}{c}\text { perlakuan } \\
2\end{array}$ & $\begin{array}{c}\text { pelakuan } \\
3\end{array}$ & \\
\hline kontrol + & 22.4 & 22.15 & 22.21 & $22.38 \pm 0.35$ \\
\hline $\begin{array}{c}\text { fraksi n- } \\
\text { heksan }\end{array}$ & 20.30 & 20.48 & 20.73 & $20.65 \pm 0.21$ \\
\hline $\begin{array}{l}\text { fraksi } \\
\text { etil } \\
\text { asetat }\end{array}$ & 18.91 & 17.56 & 18.20 & $18.32 \pm 0.53$ \\
\hline $\begin{array}{c}\text { fraksi } \\
\text { butanol }\end{array}$ & 16.37 & 18.60 & 18.45 & $17.98 \pm 1.04$ \\
\hline
\end{tabular}

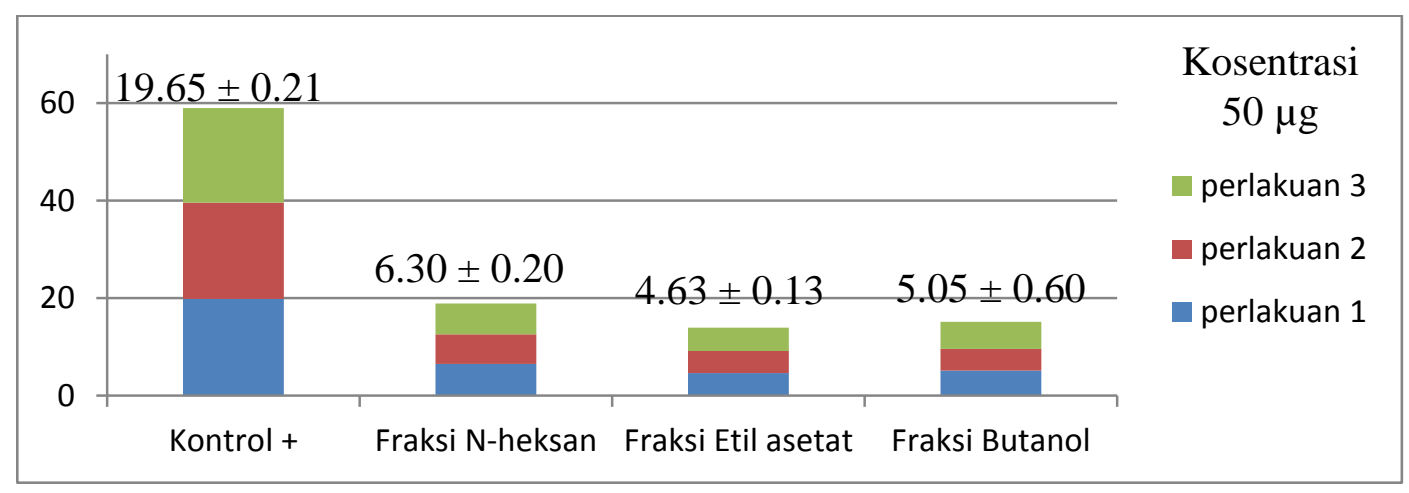

Gambar 5. Rata-Rata Diameter Zona Hambat Fraksi N-heksan, Etil Asetat, dan Butanol pada bakteri Staphylococcus aureus dengan konsentasi50 $\mu \mathrm{g} / \mathrm{disc}$. 


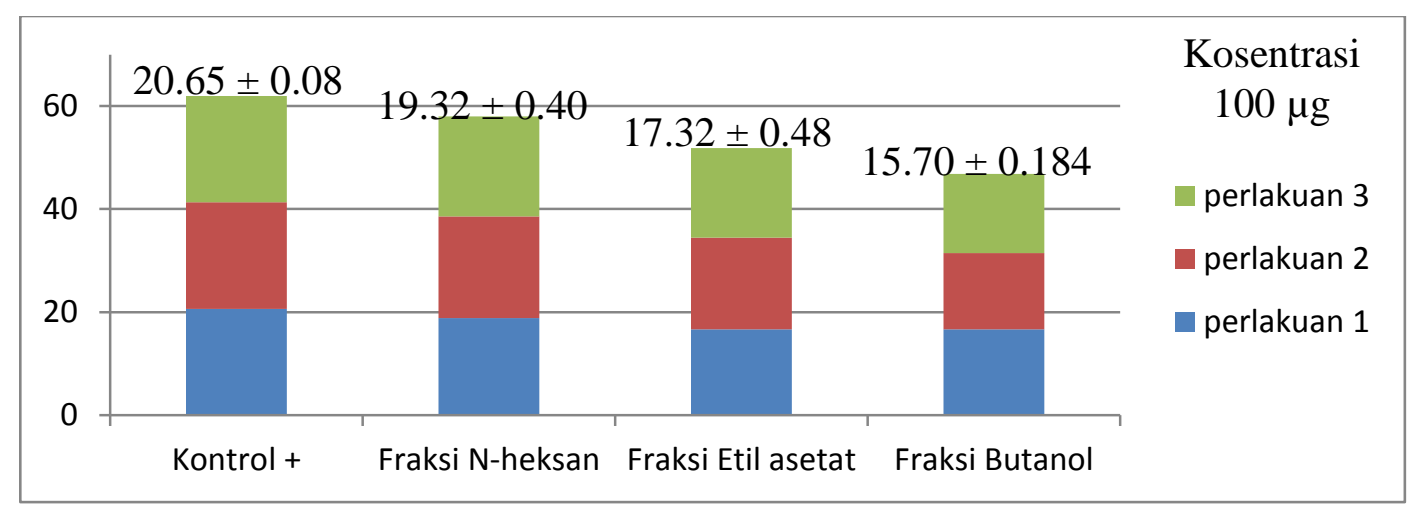

Gambar 6. Rata-Rata Diameter Zona Hambat Fraksi N-heksan, Etil Asetat, dan Butanol pada bakteri Staphylococcus aureus dengan konsentasi $100 \mu \mathrm{g} / \mathrm{disc}$.

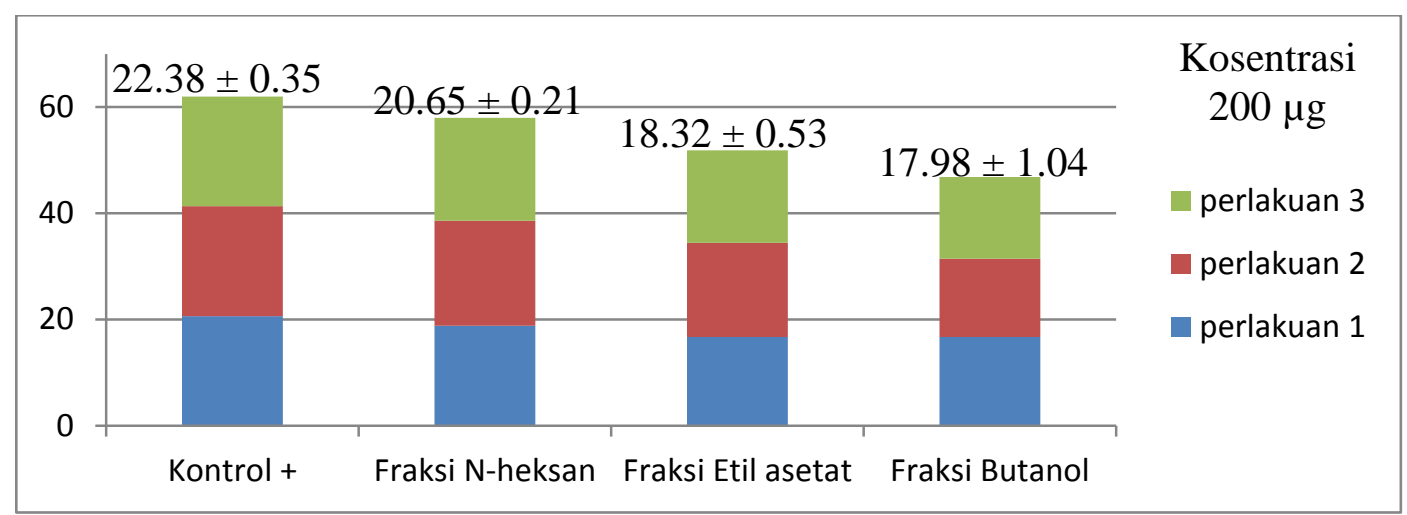

Gambar 7. Rata-Rata Diameter Zona Hambat Fraksi N-heksan, Etil Asetat, dan Butanol pada

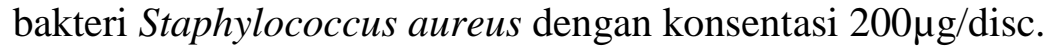

Tabel 9. Zona Hambat Terhadap Bakteri Staphylooccus epidermidis pada Konsentrasi 50 $\mu \mathrm{g} / \mathrm{disc}$.

\begin{tabular}{|c|c|c|c|c|}
\hline & \multicolumn{3}{|c|}{ Diameter zona hambat } & \multirow{2}{*}{$\begin{array}{c}\text { Rata-rata Diameter Zona } \\
\text { Hambat }(\mathrm{mm}) \pm \text { SD }\end{array}$} \\
\cline { 1 - 4 } $50 \mu \mathrm{g}$ & $\begin{array}{c}\text { perlakuan } \\
\text { kontrol }+\end{array}$ & $\begin{array}{c}\text { perlakuan } \\
2\end{array}$ & $\begin{array}{c}\text { pelakuan } \\
3\end{array}$ & $19.46 \pm 0.62$ \\
\hline fraksi n-heksan & 6.39 & 20.05 & 19.54 & $6.11 \pm 0.32$ \\
\hline fraksi etil asetat & 4.87 & 5.75 & 6.2 & $4.81 \pm 0.25$ \\
\hline fraksi butanol & 5.3 & 5.44 & 4.93 & $5.22 \pm 0.264$ \\
\hline & & & & \\
\hline
\end{tabular}


Tabel 10. Zona Hambat Terhadap Bakteri Staphylooccus epidermidis pada Konsentrasi 100 $\mu \mathrm{g} /$ disc.

\begin{tabular}{|c|c|c|c|c|}
\hline & \multicolumn{3}{|c|}{ diameter zona hambat } & \multirow{2}{*}{$\begin{array}{c}\text { rata-rata diameter zona } \\
\text { hambat }(\mathrm{mm}) \pm \mathrm{SD}\end{array}$} \\
\hline $100 \mu \mathrm{g}$ & $\begin{array}{c}\text { perlakuan } \\
1\end{array}$ & $\begin{array}{c}\text { perlakuan } \\
2\end{array}$ & $\begin{array}{c}\text { pelakuan } \\
3\end{array}$ & $21.53 \pm 0.12$ \\
\hline kontrol + & 21.4 & 21.78 & 21.62 & $19.36 \pm 0.40$ \\
\hline fraksi n-heksan & 18.79 & 19.53 & 19.40 & $17.03 \pm 0.56$ \\
\hline fraksi etil asetat & 16.6 & 17.81 & 16.47 & $15.70 \pm 0.18$ \\
\hline fraksi butanol & 15.9 & 15.65 & 15.54 & \\
\hline
\end{tabular}

Tabel 11. Zona Hambat Terhadap Bakteri Staphylooccus epidermidis pada Konsentrasi 200 $\mu \mathrm{g} /$ disc.

\begin{tabular}{|c|c|c|c|c|}
\hline & \multicolumn{3}{|c|}{ diameter zona hambat } & \multirow{2}{*}{$\begin{array}{c}\text { rata-rata diameter zona } \\
\text { hambat }(\mathrm{mm}) \pm \mathrm{SD}\end{array}$} \\
\cline { 1 - 4 } $200 \mu \mathrm{g}$ & $\begin{array}{c}\text { perlakuan } \\
1\end{array}$ & $\begin{array}{c}\text { perlakuan } \\
2\end{array}$ & $\begin{array}{c}\text { pelakuan } \\
3\end{array}$ & $22.69 \pm 0.18$ \\
\hline kontrol + & 22.60 & 22.75 & 22.52 & $20.03 \pm 0.45$ \\
\hline fraksi n-heksan & 19.38 & 19.69 & 20.53 & $19.69 \pm 0.82$ \\
\hline fraksi etil asetat & 18.84 & 19.37 & 20.59 & $18.03 \pm 0.75$ \\
\hline fraksi butanol & 18.9 & 17.65 & 17.54 & \\
\hline
\end{tabular}

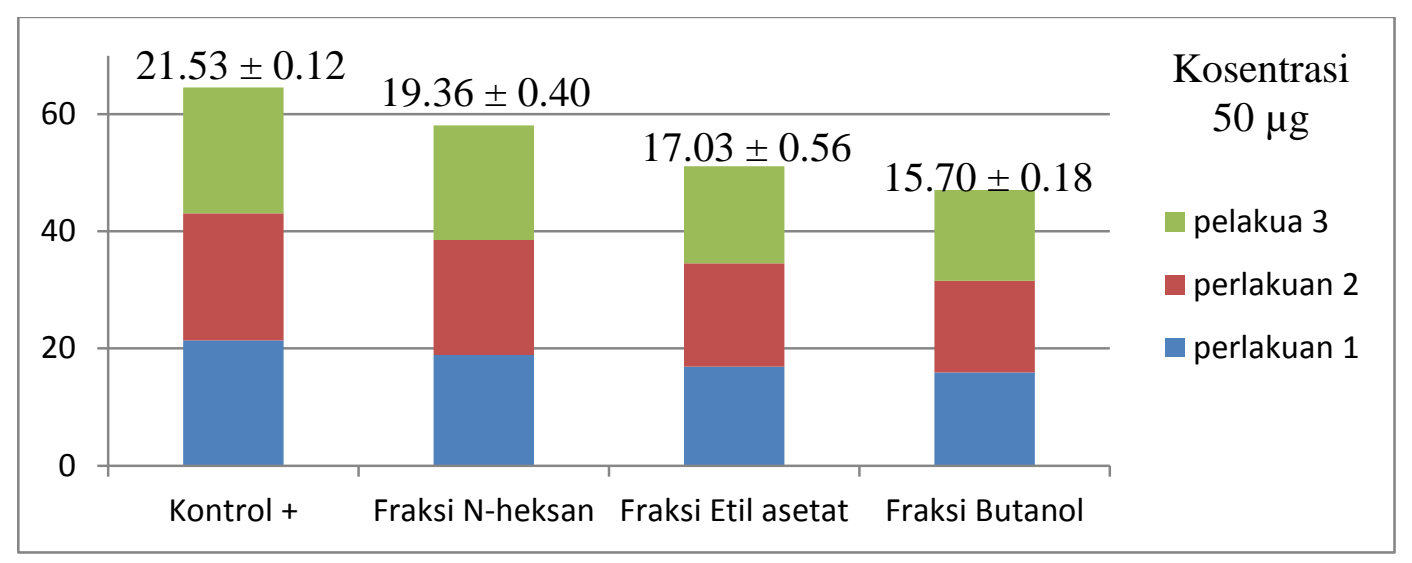

Gambar 8. Rata-Rata Diameter Zona Hambat Fraksi N-heksan, Etil Asetat, dan Butanol pada Bakteri Staphylococcus aureus dengan Konsentasi 50 $\mathrm{g} / \mathrm{disc}$. 


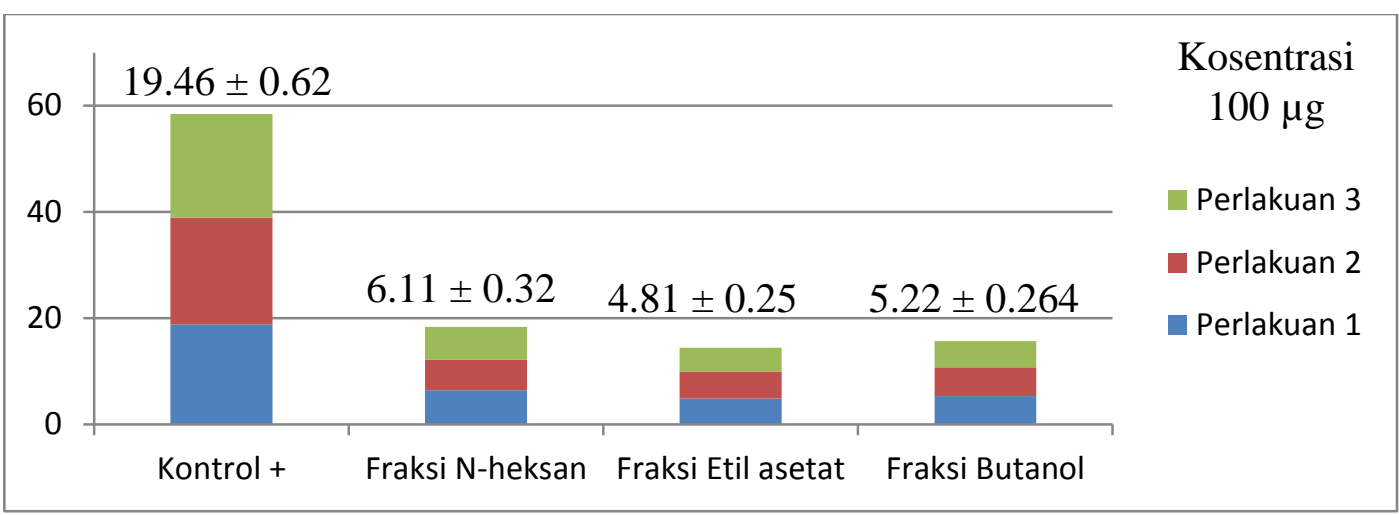

Gambar 9. Rata-Rata Diameter Zona Hambat Fraksi N-heksan, Etil Asetat, dan Butanol pada Bakteri Staphylococcus aureus dengan Konsentasi $100 \mu \mathrm{g} / \mathrm{disc}$.

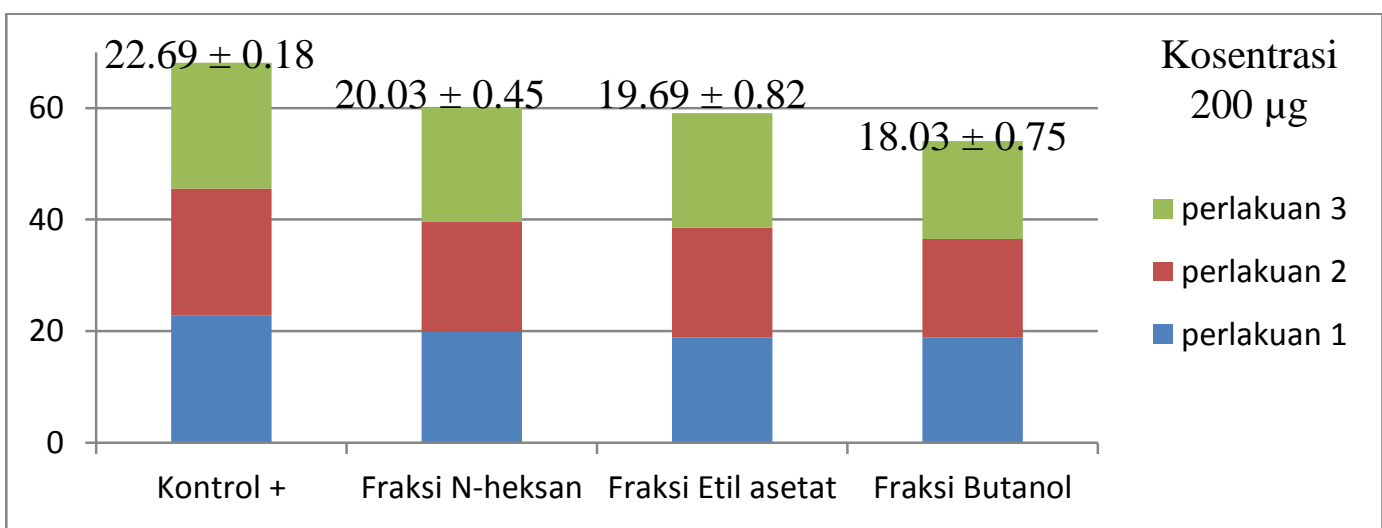

Gambar 10. Rata-Rata Diameter Zona Hambat Fraksi N-heksan, Etil Asetat, dan Butanol pada Bakteri Staphylococcus aureus dengan Konsentasi $200 \mu \mathrm{g} / \mathrm{disc}$.

Kontrol positif yang digunakan pada penelitian ini adalah klindamisin.Klindamisin merupakan golongan antibiotik yang digunakan untuk mengobati infeksi serius yang disebabkan oleh bakteri dengan cara menghentikan perkembangbiakannya dan juga untuk mengatasi infeksi bakteri gram positif. Hasil penelitian sebelumnya menyebutkan bahwa pada uji difusi klindamisin dapat menghambat pertumbuhan bakteri propionibcterium acnes dengan (diameter zona radikal $14 \mathrm{~mm}$ ) serta klindamisin aktif terhadap kokus gram positif, termasuk stafilokokus yang resisten terhadap penisilin juga terhadap bakteri anaerob sperti fragilis. Obat ini digunakan sebagai kontrol positif karena memiliki mekanisme terjadi iktan secara reversible dengan subunit ribosomal 50S, mencegah terjadinya ikatan peptida shingga akan menghambat sintesis protein bakteri; efek bakteriostatik atau bakterisidal tergantung dari konsentrasi obat, infeksi dan jenis organisme.

Uji aktivitas antibakteri dilakukan untuk mengetahui aktivitas antibakteri dengan fraksi daun pepaya terhadap Staphylococcus epidermedis, propioni bacterium acnes dan Staphylococcus aureus. Metode yang digunakan dalam penelitian ini adalah metode difusi dengan cara Kirby 
Bauer menggunakan disk. Hasil fraksi dibuat dengan menimbang sebanyak $200 \mathrm{mg}$ ekstrak dan dilarutkan dalam $5 \mathrm{ml} \mathrm{Nacl}$. Kontrol negatif yang digunakan adalah DMSO dan menggunakan kontrol positif klindamisin $30 \mu \mathrm{l} /$ disk. Berdasarkan hasil pengamatan dan analisa yang telah dilakukan, data menunjukkan bahwa pada konsentrasi $50 \mu \mathrm{g} / \mathrm{disc}, 100 \mu \mathrm{g} / \mathrm{disc}$, dan $200 \mu \mathrm{g} / \mathrm{disc}$ kelompok fraksi N-heksan menunjukkan daya hambat lebih tinggi dibandingkan dengan kelompok fraksi butanol dan etil asetat pada bakteri propionibacterium acnes, Staphylococcus aureus, dan staphylococcus epiermidis. Besarnya zona hambat yang terbentuk oleh fraksi butanol, etil asetat dan $\mathrm{N}$-heksana pada bakteri propionibacterium acnes adalah 18,41 mm, 19,74 $\mathrm{mm}$ dan 20,74 mm pada konsntrasi $200 \mu \mathrm{g} /$ disc, pada konsentrasi $100 \mu \mathrm{g} /$ disc fraksi butanol, etil astat dan N-heksana adalah 14,75 mm, 17,41 mm dan 18,75 mm, untuk konsentrasi $50 \mu \mathrm{g} /$ disc fraksi butanol, etil astat dan N-heksana adalah 16,19 mm, 14,7 mm, dan 19,66 mm. Besarnya zona hambat yang terbentuk Fraksi butanol, etil asetat dan N-heksana pada bakteri Staphylococcus aureus masing-masing adalah 17,99 mm, 18,32 $\mathrm{mm}$ dan 20,65 mm pada konsentrasi $200 \mu \mathrm{l}$, pada konsentrasi $100 \mu \mathrm{g} /$ disc fraksi butanol, etil astat dan N-heksana adalah $15,65 \mathrm{~mm}, 17,32 \mathrm{~mm}$ dan 19,32 mm, untuk konsentrasi $50 \mu 1$ masing-masing adalah 5,05 mm, 4,63 mm dan 6,30 mm. Dan untuk zona hambat yang terbentuk dari fraksi butanol, etil asetat, dan N-heksana pada bakteri staphylococcus epidermedis adalah 18,03 mm, 19,69 mm dan 20,03 mm konsentrasi $200 \mu \mathrm{l}$, pada konsentrasi $100 \mu \mathrm{g} /$ disc fraksi butanol, etil astat dan N-heksana adalah $15,70 \mathrm{~mm}, 17,03 \mathrm{~mm}$, dan 19,36 mm, untuk konsentrasi $50 \mu \mathrm{l}$ adalah 5,22 $\mathrm{mm}, 4,81 \mathrm{~mm}$, dan $6,11 \mathrm{~mm}$.

perbedaan besar kecilnya konsentrasi atau banyak sedikitnya kandungan zat aktif antibakteri yang terkandung didalamnya serta kecepatan difusi bahan antibakteri kedalam medium agar. Faktor-faktor lain yang juga dianggap dapat mempengaruhi terbentuknya zona hambat adalah kepekaan pertumbuhan antibakteri, reaksi antara bahan aktif dengan medium dan temperature inkubasi. Terbentuknya zona bening merupakan bentuk penghambatan pertumbuhan terhadap Staphyloccus epidermedis, propionibacterium acnes dan Staphylcoccus aureus.

Berdasarkan hasil penelitian yang telah dilakukan melalui uji skrining fitokimia diperoleh data berupa senyawa senyawa yang terkandung dalam ekstrak etanol daun pepaya yakni flavonoid, alkaloid, saponin, tanin, Glikosida. Hal ini sesuai dengan penelitian[7] dimana ekstrak daun pepaya memiliki senyawa aktif berupa flavonoid, alkaloid, saponin, tanin galat, tanin katekat, glikosida. Dimana senyawa-senyawa tersebut memiliki mekanisme anti bakteri yang berbeda-beda.

Flavonoid bekerja sebagai antibakteri karena kemampuannya membentuk senyawa kompleks dengan protein ekstraseluler dan terlarut sehingga dapat merusak membrane sel bakteri dan diikuti dengan keluarnya senyawa intraseluler[8]. Selain itu mekanisme lain golongan flavonoid dalam menghambat pertumbuhan bakteri adalah inhibisi lapisan biofilm pada bakteri. Lapisan biofilm adalah lapisan pada bakteri yang berfungsi mengatur permeabilitas membran sel bakteri, adanya gugus $\mathrm{OH}$ pada bakteri akan mengakibatkan gugus tersebut akan berikatan dengan komponen fosfolipid pada sel bakteri. Ikatan ini bersifat toksik bagi bakteri sehingga dapat terganggunya permeabilitas membran menyebabkan komponen dalam sel akan ikut keluar dan tekanan dari luar akan menyebabkan sel mengalami lisis. 
Alkaloid mempunyai meknisme penghambatan dengan cara berikatan dengan DNA. Hal ini diduga karea alkaloid memiliki gugus basa yang mengandung nitrogen. Gugus basa ini akan bereaksi dengan senyawa asam yang ada pada bakteri seperti DNA, yang merupakan penyusun utama inti sel. Dengan terganggunya DNA maka sintesis protein dan asam nukleat dalam sel akan terganggu, yang berkibat terganggunya metabolism sel sehingga bakteri dapat dihambat pertumbuhannya atau mengalami kematian[9].

Mekanisme saponin sebagai antibakteri dengan cara menurunkan tegangan permukaan sehingga mengakibatkan naiknya permeabilitas atau kebocoran sel dan mengakibatkan senyawa intraseluler akan keluar[10]. senyawa ini berdifusi melalui membran luar dan dinding sel yang rentan, lalu mengikat membran sitoplasma dan mengganggu dan mengurangi kestabilan itu. Hal ini menyebabkan sitoplasma bocor keluar dari sel yang mengakibatkan kematian sel. Agen antimikroba yang mengganggu membran sitoplasma bersifat bakterisida[11].

Mekanisme tanin sebagai antibakteri berkaitan dengan inhibisi enzim bakteri, dimana enzim transkriptase dan DNA topoisomerase tidak dapat terbentuk. Selain itu juga tanin memiliki aktivitas antibakteri yang berhubungan dengan menginaktifkan adhesin sel mikroba juga menginakifkan enzim dan menganggu transport protein. Untuk memelihara kelangsungan hidupya, sel mikroba perlu mensintesis protein yang berlangsung di ribosom, gangguan protein akan berakibat sangat fatal dan anti mikroba dengan mekanisme kerja yang seperti ini memiliki daya anti bakteri yang kuat. Penghambatan biosentesis protein akan bersfiat sitototoksik karena dapat menghambat pertumbuhan sel dan yang diserang adalah ribosom. Selain itu Tanin juga mempunyai target pada polipeptida dinding sel, sehingga pembentukan dinding mejadi kurang sempurna. Semua mekanisme diatas akan menyebabkan permeabilitas membran pada sel bakteri sehingga terjadi lisis karena tekanan osmotik dan pada akhirnya bakteri akan mati.

Mekanisme steroid sebagai antibakteri berhubungan dengan membran lipid dan sensitivitas terhadap komponen steroid yang menyebabkan kebocoran pada liposom. Steroid dapat berinteraksi dengan membran fosfolipid sel yang bersifat permeabel terhadap senyawa-senyawa lipofilik sehingga menyebabkan integritas membran menurun serta morfologi membran sel berubah yang menyebabkan sel rapuh dan lisis[12].

Mekanisme triterpenoid sebagai antibakteri adalah bereaksi dengan porin (protein transmembran) pada membran luar dinding sel bakteri, membentuk ikatan polimer yang kuat sehingga mengakibatkan rusaknya porin. Rusaknya porin yang merupakan pintu keluar masuknya senyawa akan mengurangi permeabilitas dinding sel bakteri yang akan mengakibatkan sel bakteri akan kekurangan nutrisi, sehingga pertumbuhan bakteri terhambat atau mati. Mekanisme aksi dari golongan senyawa triterpenoid juga berkaitan dengan penghambatan glycolisis, sintesis asam lemak, sintesis asam amino dan di sintesis peptidoglikan, semua mekanisme ini sangat berpengaruh bagi pertumbuhan bakteri karena merupakan bahan bahan yang sangat dibutuhkan untuk keberlangsungan hidupnya[13].

Hasil uji pendahuluan menunjukkan bahwa kontrol positif yakni klindamisin dapat menghambat pertumbuhan ketiga bakteri. Hasil selanjutnya dari ketiga fraksi etil astetat, Nheksana dan butanol memiliki zona hambat pada bakteri Staphylococcus epidermedis, propionibacterium acnes dan Staphylococcus aureus paling besar terdapat pada fraksi Nheksana. Sehingga fraksi N-heksana dapat dilanjutkan untuk pengujian KHM. 
Pengaruh fraksi daun pepaya terhadap aktivitas penghambatan bakteri dapat diketahui dengan menganalisis data secara kuantitatif. Berdasarkan uji aktivitas terdapat beberapa faktor yang berpengaruh terhadap daya hambat yakni adalah kelompok konsentrasi, kelompok fraksinasi dan kelompok bakteri. Berdasarkan uji statistik terhadap kelompok konsentrasi diperoleh nilai sig 0,000 yang mana artinya pengaruh konsentrasi terhadap daya hambat bakteri signifikan, lalu pada kelompok fraksinasi diperoleh nilai sig 0,000 yang artinya fraksinasi mempengaruhi daya bunuh bakteri secara signifikan, kemudian pada kelompok bakteri diperoleh nilai sig 0,465. Dari variabel fraksinasi bisa dilihat bahwa fraksinasi mempengaruhi daya hambat dari bakteri Propionibcterium acnes, Staphylococusn epidermedis maupun Staphylococcus aureus. Dari uji post hoc dari ketiga fraksinasi pada fraksi N-heksan memilliki nilai mean difference yang paling besar diantara fraksi etil asetat dan fraksi butanol beruturut-turut yakni 1,544 dan 3,011 dengan nilai $\mathrm{P}$ value $0,000<0,005$ yang artinya kelompok fraksinasi yang memiliki pengaruh yang signifikan terhadap daya hambat bakteri adalah fraksi N-heksan memiliki kemampuan dalam membunuh bakteri Propionibactrium acnes, Staphylococcus epidermdis maupun Staphylococcus aureus dibandingkan dengan dua fraksi lainnya.

Lalu untuk uji kadar hambat minimum ada beberapa faktor yang berpengaruh terhadap pertumbuhan bakteri yakni kelompok konsentrasi dan fraksi yang digunakan. Berdasarkan uji statistik pada kelompok konsentrasi diperoleh nilai sig 0,000 yang artinya kelompok konsentrasi berpengaruh signifikan terhadap daya hambat minimum bakteri. Lalu pada fraksinasi diperoleh nilai sig 0,000 yang artinya adanya perbedaan kelarutan dan kekuatan terhadap ketiga bakteri yang dapat mempengaruhi daya hambat minimum secara signifikan. Untuk melihat konsentrasi mana yang memiliki potensi yang lebih baik dalam daya hambat minimum dilakukan uji post hoc. Berdasarkan uji post bisa disimpulkan bahwa pada konsentrasi $100 \mu \mathrm{g} / \mathrm{disc}$ memiliki daya hambat paling besar tetapi tidak berbeda signifikan dengan konsentrasi $90 \mu \mathrm{g} / \mathrm{disc}$ hal ini dilihat dari nilai signifikan yang diperoleh yaitu $0,955>0,005$.

\section{KESIMPULAN}

Bedasarkan Uji aktivitas daya hambat tertinggi dalam menghambat pertumbuhan bakteri Staphylococcus epidermedis, Propionibacterium acnes dan Staphylococcus aureus adalah fraksi N-heksan konsentraasi $200 \mu \mathrm{g}$ /disc rerata zona hambat 20,03 \pm 0,45 mm, 20,65 \pm 0,21 $\mathrm{mm}$, dan 20,74 $\pm 0,11$ mmdaun pepaya dan nilai konsentrasi hambat minimum yang diperoleh dari ekstrak etanol daun pepaya terhadap pertumbuhan Staphylococcus epidermidis, Propionibacterium acnes dan Staphylococcus aureus masing-masing adalah $80 \mu \mathrm{g}$.

\section{DAFTAR RUJUKAN}

1. Djuanda, A., Hamzah, M., dan Aisah, S. (1999). Ilmu penyakit kulit dan kelamin. Jakarta: Balai Penerbit FKUI.

2. Wasitaatmadja, S.M. (1997). Penuntun Ilmu Kosmetik Medik. Jakarta: UI-Press. Hal: 28 dan 122 
3. Ersam, T. (2004). "Keunggulan Biodiversitas Hutan Tropika Indonesia dalam Merekayasa”. Seminar Nasional Kimia VI, 1-16.

4. Rijayanti, Rika Pratiwi., Sri Luliana., Heru Fajar Trianto. 2014. Uji Aktivitas Antibakteri Ekstrak Etanol Daun Mangga Bacang (Mangifera foetida L) Terhadap Staphylococcus aureus. Jurnal Universitas Tanjungpura. 2014 (1- 19).

5. Saepudin, S. Padmasari, P. Hidayanti, and E.S. Ningsih. 2013. Kepatuhan Penggunaan Obat pada Pasien Hipertensi di Puskesmas. Jurnal Farmasi Indonesia6(1): 246-253.

6. Markham, K.R., 1988, Cara Mengidentifikasi Flavonoid, diterjemahkan oleh kosasih Padmawinata, 19-21, 31, 41-47, 65-75, Penerbit ITB, Bandung.

7. Hartati E. 1998. Suplementasi Minyak Lemuru dan Seng ke dalam Ransum yng mengandung Silse Pod Kakao dan Urea untuk Memacu Pertumbuhan Sapi Holstein Jantan. Disertasi. Program Pasca Sarjana IPB, Bogor.

8. Mercy Ngajow, Jemmy Abidjulu, Vanda S. Kamu. (2013).Pengaruh Antibakteri Ekstrak Kulit Batang Matoa (Pometia pinnata) terhadap Bakteri Staphylococcus aureus secaraIn vitro, Jurusan Kimia, FMIPA, Jurnal MIPA Unsrat Online 2(2) 128-132, Unsrat, Manado.

9. Cowan, N., Nugent, L. D., Elliot, E. M., Ponomarev, I. dan Saults, J. S. (1999) The role of attention in the development of short-term memory: Age differences in the verbal span of apprehension.

10. Nuria, M. C., Faizatun, A., Sumantri. 2009. Uji Aktivitas Antibakteri Ekstrak Etanol Daun Jarak Pagar (Jatropha Curcas L) Terhadap Bakteri Staphylococcus Aureus ATCC 25923.

11. Cavalieri, S.J., I.D. Rankin., R.J. Harbeck., R.S. Sautter., Y.S. McCarter., S.E. Sharp., J.H. Ortez., dan C.A. Spiegel. (2005) Manual of Antimicrobial Susceptibility Testing, American Society for Microbiology, USA.

12. Madduluri, Suresh. Rao, K.Babu. Sitaram, B. In VitroEvaluation of Antibacterial Activity of Five Indegenous Plants Extract Against Five Bacterial Pathogens of Human, International Journal of Pharmacy and Pharmaceutical Sciences, 2013:5(4): 679-684.

13. Park, Soon-Nang, Yun Kyong lin. (2017). Antimirobal Mechanismeof Oleanolic and Ursolic Acid on Streptococcus mutans UA159. Curr Microbial. Doi 10.1007/s00284 017. 1344-5. 